\title{
Farnesoid X Receptor in Mice Prevents Severe Liver Immunopathology During Lymphocytic Choriomeningitis Virus Infection
}

\author{
Nadine Honke Namir Shaabani $\mathrm{i}^{\mathrm{a}, \mathrm{b}, \mathrm{d}}$ Cornelia Hardt ${ }^{\mathrm{a}} \quad$ Caroline Krings ${ }^{\mathrm{b}}$ \\ Dieter Häussinger ${ }^{b}$ Philipp A. Lang ${ }^{b, c}$ Verena Keitel ${ }^{b} \quad$ Karl S. Lang ${ }^{a, b}$ \\ Institute of Immunology, University Hospital Essen, Medical Faculty, University of Duisburg-Essen, \\ Essen, bepartment of Gastroenterology, Hepatology, and Infectious Diseases, Heinrich-Heine- \\ University, Düsseldorf, 'Department of Molecular Medicine II, Medical Faculty, Heinrich-Heine- \\ University Düsseldorf, Düsseldorf, Germany; 'Department of Immunology and Microbial Science, \\ The Scripps Research Institute, La Jolla, CA, USA
}

\section{Key Words}

$\mathrm{NR} 1 \mathrm{H} 4 \cdot \mathrm{FXR} \cdot \mathrm{IFN}-\mathrm{I} \cdot$ Bile acids $\bullet$ LCMV $・$ Monocytes

\begin{abstract}
Background: Bile acids (BAs) are steroid molecules that are synthesized in the liver. In addition to their important role as a surfactant in solubilizing lipids and promoting the absorption of lipids in the gastrointestinal tract, they act as inflammagens. The role of BAs and their receptor farnesoid X receptor (FXR) during viral infection has not been studied in detail. Methods: By using FXR-deficient mice, we investigated the role of bile acid receptor FXR during infection with lymphocytic choriomeningitis virus (LCMV). The importance of FXR in inducing IFN-I and monocytes proliferation were investigated and viral titers and T cell exhaustion were analyzed at different time points. Results: This study shows that controlled levels of BAs activate FXR in hepatocytes and FXR in response upregulates the production of type I interferon. In turn, FXR maintains BAs within a balanced range to inhibit their toxic effects. The absence of FXR results in high levels of BAs, which inhibit the proliferation of monocytes and result in a defect in viral elimination, consequently leading to $T$ cell exhaustion. Conclusion: We found that FXR contributes to IFN-I production in hepatocytes and balances BA levels to inhibit their toxic effects on monocytes. Lang P.A., Keitel V. and Lang K.S. contributed equally to this manuscript and thus share the last authorship

Karl S. Lang

and Nadine Honke
Institute of Immunology, Hufelandstraße 55, 45147 Essen, (Germany)

Tel. +492017234273, Fax +492017235410

E-Mail karlsebastian.lang@uk-essen.de / nadine_honke@yahoo.de 


\section{Introduction}

The liver is a central organ that is responsible for vital functions, including the detoxification and metabolism of many drugs, the production of enzymes, cytokines, and the uptake of viruses through Kupffer cells. Additionally, the liver is important for the synthesis of bile acids (BAs). In recent years, many studies have shown that BAs not only promote the absorption of lipids because of their amphipathic nature but are also considered to be signaling molecules in hepatocytes that stimulate the production of proinflammatory cytokines [1]. However, BAs can also increase the replication of viruses such as hepatitis C [2] and hepatitis B viruses $[3,4]$. Therefore, their influence on the immune system is still controversial.

Two BA receptors have been described. The first, TGR5 (also known as GPAR1, M-BAR, or BG37), is a surface receptor that belongs to the family of G protein-coupled receptors (GPCRs). TGR5 is expressed in various tissues, such as ileum and colon, sinusoidal endothelial cells, and macrophages [5-9]. The second receptor is an intracellular BA-activated nuclear receptor called farnesoid X receptor (FXR; also known as nuclear receptor subfamily 1 , group $\mathrm{H}$, member 4; NR1H4). FXR belongs to the nuclear hormone receptor (NHR) superfamily, which is composed of 49 functional genes [10]. Many studies have shown that both TGR5 and FXR receptors may contribute to immune function $[8,11-16]$. The importance of FXR emerged from its ability to regulate many genes involved in liver cancer $[17,18]$, hepatic inflammation [19, 20], hepatic fibrosis [21, 22], triglycerides, cholesterol [23], glucose [24, $25]$, and BA homeostasis [26, 27]. FXR is mainly expressed in tissues that have contact with BAs, such as liver, intestine, and kidney [28-30]. In the liver, FXR is mainly expressed in hepatocytes (parenchymal cells), at levels as much as 20 -fold higher than those in nonparenchymal cells [31,32].

BAs are endogenous ligands for FXR. The hydrophobic BA chenodeoxycholic acid (CDCA) is the strongest activator of FXR [33, 34]. In turn, FXR induces the small heterodimer partner (SHP), which downregulates cholesterol $7 \alpha$-hydroxylase (Cyp7a1) and consequently reduces the synthesis of BAs [35]. Recently, a few reports have described the roles of FXR as a player at the immunological level $[11-14,19,20,36]$. The change in its expression can influence the production of some cytokines, but its exact role in controlling viral infection has not yet been determined.

In our study, using FXR knockout ( $\mathrm{FXR}^{-/-}$) mice, we found that infection with lymphocytic choriomeningitis virus (LCMV) leads to the release of BAs; this release signals the liver, through FXR, to produce type I interferon (IFN-I) in hepatocytes. Additionally, the feedback mechanism of BAs through FXR guarantees low levels of BAs, thereby avoiding their negative role in monocyte expansion. This feedback mechanism allows efficient proliferation and infiltration of immune cells to the site of infection, consequently leading to rapid elimination of the pathogen and saving the adaptive immune cells from exhaustion due to viral overload.

\section{Material and Methods}

Mice

All experiments were performed with animals housed in single ventilated cages, under the authorization of the Veterinäramt Nordrhein Westfalen (Düsseldorf, Germany) and in accordance with the German law for animal protection. All mice were sex matched and they were used 10-14 weeks old. FXR - $^{-1}$ and $\mathrm{CD}^{-/-}$mice were maintained on a C57BL/6 background. P14/CD45.1 mice expressing a T cell receptor (TCR) transgene specific for LCMV glycoprotein aminoacid 33 to 41 (LCMV-GP33-41) were also maintained on a C57BL/6 background and were used for adoptive transfer experiments [37]. All the experimental protocols were approved by the Nordrhein Westfalen Landesamt für Natur, Umwelt und Verbraucherschutz (Recklinghausen, Germany). 


\section{Cellular Physiology Cell Physiol Biochem 2017;41:323-338 \begin{tabular}{ll|l} 
DOI: 10.1159/000456168 & Ond Biochemistry \\
Publisned online: January 30, 2016 & $\begin{array}{l}\text { 2017 The Author(s). Published by S. Karger AG, Basel } \\
\text { www.karger.com/cpb }\end{array}$
\end{tabular}}

Honke et al.: FXR Prevents Immunopathology During LCMV Infection

Virus, Beads

LCMV strain WE was originally obtained from Prof. Dr. F. Lehmann-Grube (Heinrich Pette Institute, Hamburg, Germany) and was propagated in L929 cells. Mice were infected intravenously with LCMV-WE at the indicated doses. Latex beads (Fluoresbrite, $4.55 \times 10^{10}$ particles per $\mathrm{mL}$ ) were obtained from Polysciences (Warrington, PA, USA) and had a diameter of $1 \mu \mathrm{m}$.

Viral uptake

Mice were intravenously infected with $2^{\mathrm{x}} 10^{6}$ PFU LCMV-WE. After 1, 10, and $60 \mathrm{~min}$, LCMV viral titer was measured in the blood by plaque assay.

Measurement of bile acids, ALT, AST, bilirubin, and LDH

Biochemical analyses were performed by the Central Laboratory, Clinic of the University DuisburgEssen, Essen, Germany or MVZ Laboratory Dr. Limbach, Heidelberg, Germany.

Histology

Histological analyses were performed on snap-frozen tissues and LCMV was visualized with a monoclonal antibody against LCMV nucleoprotein (VL4; made in-house). Liver macrophages (Kupffer cells) were stained with anti-F4/80 (BM8; eBioscience, San Diego, CA, USA).

Plaque assay

LCMV titers were measured with a plaque-forming assay using MC57 cells, as previously described [38].

Total RNA extraction, cDNA synthesis, and quantitative real-time PCR

RNA was isolated from liver tissue with the RNA Mini Kit (Qiagen, Hilden, Germany) or from FACSsorted cells with Trizol (Thermo Fisher Scientific, Waltham, MA, USA). Quantitation of RNA was performed with a NanoDrop ND-1000 spectrophotometer (Thermo Fisher Scientific). The RNA was reverse-transcribed to cDNA with the Quantitect Reverse Transcription Kit (Qiagen). Gene expression analysis was performed with assays from Qiagen (GAPDH, Ifnar, Oas1, Mx1, Ifn $\alpha 4$, and Ifn $\beta 1$ ) or Eurofins (NP and GP). For analysis, the expression levels of all target genes were normalized against glyceraldehyde-3-phosphate dehydrogenase (GAPDH; $\Delta$ cycle threshold [Ct]). Gene expression values were then calculated by the delta delta $\mathrm{Ct}(\Delta \Delta \mathrm{Ct})$ method, with the mean of the control group as the calibrator to which all other samples were compared. Relative quantities (RQs) were determined with the equation $R Q=2^{-\Delta \Delta C t}$.

\section{Depletion of macrophages}

Macrophages were depleted by intravenous injection of $200 \mu \mathrm{L}(50 \mathrm{mg}$ ) clodronate-encapsulated liposomes in phosphate-buffered saline (PBS) on day -1 of infection [39].

Sorting of $\mathrm{F} 4 / 80^{+} \mathrm{CD} 11 b^{+}$macrophages

Liver was digested with Liberase DNAse (Roche, Basel, Switzerland) and stained with anti-F4/80 (eBioscience) and anti-CD11b (eBioscience). After incubation for $30 \mathrm{~min}, \mathrm{~F} 4 / 80^{+} \mathrm{CD} 11 \mathrm{~b}^{+}$cells were washed and sorted by FACS (BD FACS Aria III, BD Bioscience, Franklin Lakes, NJ, USA).

\section{Flow cytometry}

Lymphocytes were stained with anti-CD8 (53-6.7; BD Bioscience). For measurement of intracellular IFN- $\gamma$, cells were restimulated with glycoprotein 33 (GP33; Strasbourg, France) for 6 h, fixed with 2\% formaldehyde (Sigma-Aldrich; Steinheim, Germany) for $10 \mathrm{~min}$, permeabilized with saponin, and stained with anti-IFN- $\gamma$ antibody (eBioscience).

Tetramers were provided by the National Institutes of Health (NIH) Tetramer Facility (Emory University, Atlanta, GA, USA). Staining was performed as previously described [40], Briefly, blood and cells were stained with allophycocyanin (APC)-labeled GP33 MHC class I tetramers (GP33/H-2Db) for 15 minutes at $37^{\circ} \mathrm{C}$. After incubation, the samples were stained with anti-CD8 peridinin-chlorophyll-protein complex (PerCP; BD Biosciences) for $30 \mathrm{~min}$ at $4^{\circ} \mathrm{C}$. Erythrocytes were then lysed with $1 \mathrm{ml}$ BD lysing solution (BD Biosciences), washed once, and analyzed with a flow cytometer LSR Fortessa (BD Biosciences). Absolute 


\section{Cellular Physiology Cell Physiol Biochem 2017;41:323-338 \begin{tabular}{l|l|l} 
and Biochemistry & DOI: 10.1159/000456168 & $\begin{array}{l}\text { C) } 2017 \text { The Author(s). Published by S. Karger AG, Basel } \\
\text { www.karger.com/cpb }\end{array}$
\end{tabular} \\ Honke et al.: FXR Prevents Immunopathology During LCMV Infection}

numbers of GP33-specific CD8 ${ }^{+} \mathrm{T}$ cells were calculated by fluorescence-activated cell sorting (FACS) analysis using fluorescent beads (BD Biosciences).

\section{Lymphocyte transfer}

Lymphocyte transfer was done as previously described [41], Briefly, $10^{7}$ splenocytes from P14 mice expressing CD45.1 were labelled with CFSE $(1 \mu \mathrm{M}$, Invitrogen, Carlsbad, CA, USA) and were injected intravenously into $\mathrm{FXR}^{-1-}$ or C57BL/6 WT mice on day 12 after infection with $2^{\mathrm{x}} 10^{6} \mathrm{PFU}$ LCMV-WE. Two days later (on day 14 after LCMV infection), the proliferation of P14 T cells was assessed in the spleen by CFSE dilution and flow cytometry.

\section{Bone marrow chimeras}

To generate bone marrow chimeras, we irradiated recipient mice with $9.5 \mathrm{~Gy}$ (320 kV X-rays, $3 \mathrm{~Gy} /$ min, $0.35 \mathrm{~mm}$ copper $+1.5 \mathrm{~mm}$ aluminium filter; Pantak-Seifert, Ahrensburg, Germany) on day -1 . On the next day, $10^{7}$ bone marrow cells were transferred. After 15 days, clodronate liposomes were administered to ensure macrophage exchange in WT $>\mathrm{WT}, \mathrm{FXR}^{-/-}>\mathrm{WT}$, WT $>\mathrm{FXR}^{-1-}$, and $\mathrm{FXR}^{-/-}>\mathrm{FXR}^{-1-}$ chimeras. LCMV infection was performed after 30 days.

\section{Isolation of primary hepatocytes}

Primary hepatocytes were isolated from murine livers by collagenase perfusion, as described previously [42]. The hepatocytes were cultured in Williams' medium E (Biochrom, Berlin, Germany) containing 10\% fetal bovine serum (FBS; Biochrom), and L-glutamine-penicillin-streptomycin (Sigma-Aldrich, Steinheim, Germany).

\section{Treatment of cells}

For in vitro infections, primary hepatocytes from C57BL/6 WT mice were seeded at $3^{\mathrm{x}} 10^{5}$ cells per well in a 6-well plate and were infected with LCMV-WE at a multiplicity of infection (MOI) of 1 or left uninfected. Cells were additionally treated with the FXR agonist GW4064 (1 $\mu \mathrm{M}$; Sigma-Aldrich) or left untreated. After 6 and 24 h, hepatocytes were washed twice with PBS.

Primary hepatocytes from WT and $\mathrm{FXR}^{-/-}$mice were seeded and infected as described above. Cells were additionally treated with CDCA (50 $\mu$ M; Sigma-Aldrich) or left untreated. After $24 \mathrm{~h}$, hepatocytes were washed twice with PBS, and RNA was isolated as described above.

Bone marrow cells were isolated from femurs and tibias of WT and $\mathrm{FXR}^{-/-}$mice. After elimination of erythrocytes, bone marrow cells were cultured in very low endotoxin Dulbecco's Modified Eagle's Medium (VLE-DMEM) supplemented with 10\% fetal bovine serum (FBS; Biochrom, Berlin, Germany) and $0.1 \%$ 2-mercaptoethanol ( $\beta$-ME; Sigma-Aldrich, Steinheim, Germany) in the presence or absence of GMCSF. After $15 \mathrm{~min}, 2^{\mathrm{x}} 10^{6}$ bone marrow cells were additionally treated with CDCA (50 $\mu \mathrm{M}$; Sigma-Aldrich) or left untreated for additional $15 \mathrm{~min}$. Cells were lysed with sodium dodecyl sulfate (SDS) buffer for immunoblotting. For analysis of $\mathrm{Ly}^{6} \mathrm{C}^{+}$cell numbers, bone marrow cells were treated with or without CDCA

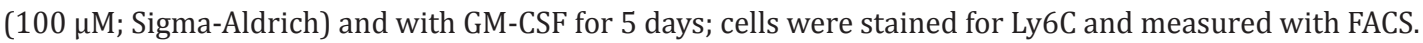

\section{Immunoblotting}

Bone marrow cells from WT and $\mathrm{FXR}^{-/-}$mice were lysed with boiling SDS buffer (Sigma-Aldrich; $1.1 \%$ SDS, $11 \%$ glycerol, $0.1 \mathrm{M}$ Tris; pH 6.8) with 10\% 2-mercaptoethanol ( $\beta$-ME; Sigma-Aldrich). Total cell extracts were examined by $10 \%$ SDS polyacrylamide gel electrophoresis (SDS-PAGE) and were transferred onto Whatman nitrocellulose membranes (GE Healthcare, Freiburg, Germany) by standard techniques. Membranes were blocked for $1 \mathrm{~h}$ in 5\% bovine serum albumin (BSA; PAA Laboratories, Pasching, Austria) / 5\% nonfat dried milk powder (AppliChem, Darmstadt, Germany) in Tris-buffered saline (TBS, Calbiochem, San Diego, CA, USA) supplemented with 1\% Tween-20 and incubated with the following antibodies: antiphospho-p44/42 (p-Erk1/2; Cell Signaling Technologies, Danvers, MA, USA) or anti-GAPDH (Meridian Life Science, Memphis, TN, USA). Antibody binding was detected by horse radish peroxidase (HRP)-conjugated anti-mouse immunoglobulin G (IgG) antibodies (BIO RAD, Munich, Germany). Signals were detected with the BIO RAD ChemiDoc imaging system and analyzed with the manufacturer's software. Images have been cropped for purposes of presentation. 


\section{Cellular Physiology Cell Physiol Biochem 2017;41:323-338

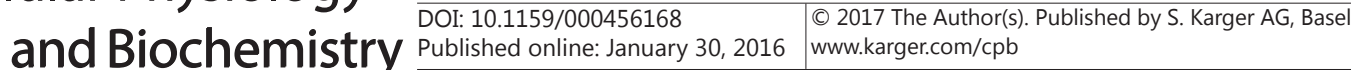 \\ Honke et al.: FXR Prevents Immunopathology During LCMV Infection}

Antibody treatment

LCMV-WE-infected mice were intravenously treated with RB6-8C5 antibody (Bioxcell, West Lebanon, NH, USA; $200 \mu$ g per mouse) on day 3 after LCMV infection to deplete Gr-1+ myeloid cells and to analyse viral load (by plaque assay and histological analysis), or were treated additionally on days 7 and 11 after infection for T cell measurement.

Statistical analysis

Data are expressed as mean \pm S.E.M. Student's $t$-test was used to detect statistically significant differences between groups. Significant differences between several groups were detected by two-way analysis of variance (ANOVA) with Bonferroni or Dunnett post hoc tests. The level of statistical significance was set at $P<0.05$. Each data reflect results from one experiment unless it is mentions in the figure legend that they are pooled from several experiments.

Ethics Statement

Animal experiments were carried out with approval of the "Landesamt für Natur, Umwelt und Verbraucherschutz Nordrhein-Westfalen" (LANUV), Germany (approval number: 84-02.04.2011.A282 and 84-02.04.2011.A246) in accordance with the German laws for animal protection. Animal care and documentation was supervised by the central animal laboratory of the University Hospital Essen, Essen, Germany.

\section{Results}

The role of bile acids and their receptor FXR during LCMV infection

To determine whether the secretion of BAs is upregulated during LCMV infection, we measured the BAs in the blood serum of C57BL/6 wild-type (WT) mice after they had been infected with the acute strain of LCMV (LCMV-WE). We found that the secretion of BAs was increased 10 days after LCMV infection (Fig. 1A). This increase is directly balanced by a feedback mechanism through FXR, because the absence of FXR led to persistently high serum levels of BAs (Fig. 1A). In line with this finding, we noticed that, in contrast to C57BL/6 WT mice, $\mathrm{FXR}^{-/-}$mice exhibited high levels of aspartate aminotransferase (AST) and alanine aminotransferase (ALT). The lactate dehydrogenase (LDH), an indicator of parenchymal injury, appeared similar in WT and $\mathrm{FXR}^{-/-}$mice at day 10 after infection, but was significantly different at day 15 and 20 indicating that WT mice recovered earlier from liver cell damage. More severe liver cell damage in $\mathrm{FXR}^{-/-}$mice is also indicated by impaired bilirubin metabolism (Fig. 1B). To check whether LCMV infection leads to elevated levels of BAs directly or is arise from $\mathrm{CD}^{+} \mathrm{T}$ cell-dependent liver immunopathology, we measured BAs in C57BL/6 WT and CD8 ${ }^{-/-}$mice after LCMV infection. We found that CD8 ${ }^{+} \mathrm{T}$ cells are responsible for the destruction of hepatocytes and release of BAs (Fig. 1C). Taken together, as a consequence of infection liver cell damage is more severe in $\mathrm{FXR}^{-/-}$mice than in WT mice and liver inflammation sustains only in $\mathrm{FXR}^{-/-}$mice. We conclude that FXR and their BA ligands play an important role during LCMV infection.

FXR is essential for controlling viral replication in Kupffer cells

Next, we questioned whether the liver damage in $\mathrm{FXR}^{-/-}$mice was due to a defect in virus control. To answer this question, we measured the viral titer in various organs after infection with LCMV. The absence of FXR led to higher viral replication in the liver, whereas FXR-deficiency had no impact on the viral titer in other investigated organs (Fig. 2A). Histological staining showed that virus is replicating in both Kupffer cells and hepatocytes in FXR-deficient mice but only in Kupffer cells in WT mice (Fig. 2B). This higher viral titer in the liver was not due to phagocytic activity, because initial viral uptake from the blood was similar in WT and $\mathrm{FXR}^{-/-}$mice (Fig. 2C). This finding indicated that naive Kupffer cells have no difficulty in the phagocytosis of virus. We speculated that the Kupffer cells of FXRdeficient mice cannot control the virus; therefore, we sorted Kupffer cells from LCMV- 
infected WT and $\mathrm{FXR}^{-/-}$mice and measured the expression of viral genes. The expression of LCMV glycoprotein and nucleoprotein in Kupffer cells was higher in $\mathrm{FXR}^{-1-}$ mice than in WT mice (Fig. 2D).

To assess the phagocytic efficiency of Kupffer cells during infection, we infected WT and $\mathrm{FXR}^{-/-}$mice with LCMV for 5 days. We then injected fluorescent latex beads into the mice and after 1 hour we measured the uptake of beads in the liver. Kupffer cells of WT mice are more efficient in taking up beads than Kupffer cells of FXR ${ }^{-/-}$mice (Fig. 2E). From these results, we conclude that the absence of FXR leads to a defect in the ability of Kupffer cells to control virus during infection, with the consequence of higher viral replication in the liver.

FXR increases the infiltration of immune cells to the infected organs

In an earlier study, we found that Kupffer cells suppress viral replication in an IFN-Idependent manner $[42,43]$. In the current study, we hypothesized that the defect of Kupffer cells in $\mathrm{FXR}^{-/-}$mice was due to a reduction in the antiviral effect. To test this theory, we measured the antiviral genes (Oas1 and Mx1) in resident liver macrophages (Kupffer cells) sorted by FACS. Indeed, we found that, in the absence of FXR, the expression of antiviral genes by Kupffer cells was lower than in WT mice (Fig. 3A). Speculating that IFN-I in situ is reduced, we measured the gene expression of IFN-I (Ifn $\alpha 4$ and Ifn $\beta 1$ ) in the liver under naïve conditions and after infection with LCMV. Indeed, IFN-I gene expression was significantly higher in WT mice than in $\mathrm{FXR}^{-/-}$mice after infection (Fig. 3B). We concluded that the higher viral titer in Kupffer cells results from the reduction of IFN-I production in $\mathrm{FXR}^{-/-}$mice.

A

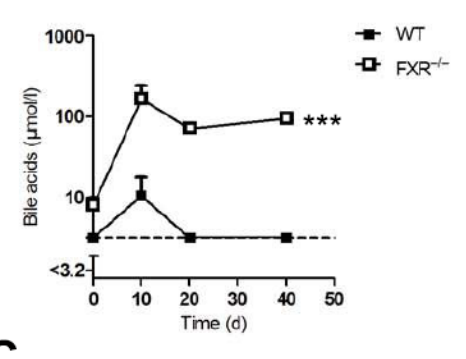

C

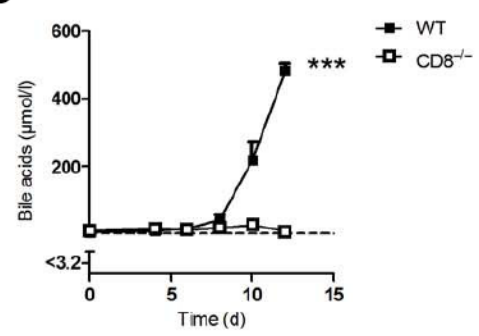

B
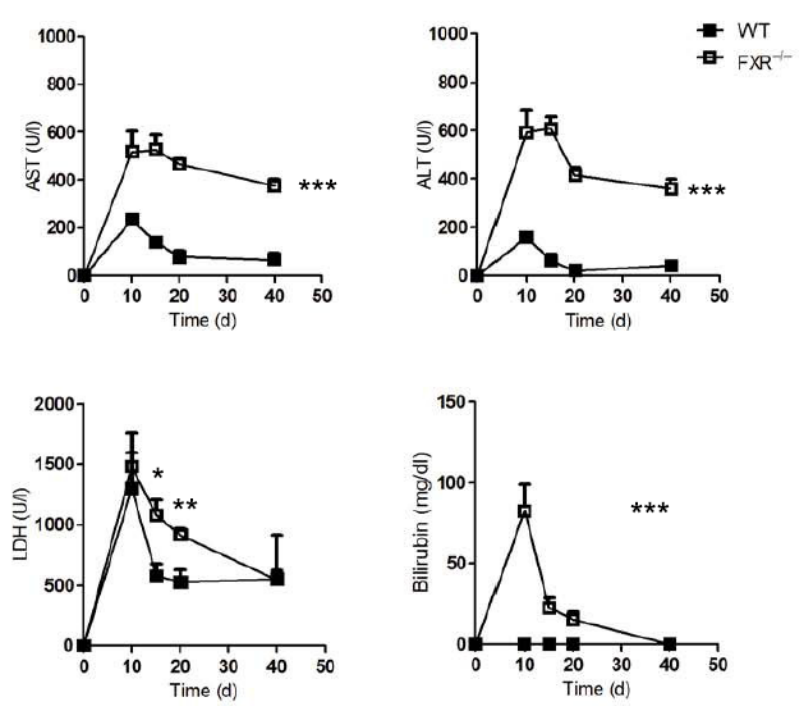

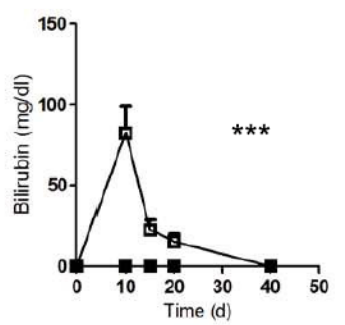

Fig. 1. The role of bile acids and farnesoid $\mathrm{X}$ receptor during infection with lymphocytic choriomeningitis virus. (A) Bile acid titers in C57BL/6 wild-type (WT) and farnesoid X receptor-knockout (FXR ${ }^{-1}$ ) mice intravenously infected with $2^{\mathrm{x}} 10^{4}$ PFU lymphocytic choriomeningitis virus strain WE (LCMV-WE; $\mathrm{n}=4-5$ ). (B) Aspartate aminotransferase (AST), alanine aminotransferase (ALT), lactate dehydrogenase (LDH), and bilirubin parameters were measured in the serum of C57BL/6 WT and $\mathrm{FXR}^{-/-}$mice intravenously infected with $2^{\mathrm{x}} 10^{4}$ plaque-forming units (PFU) LCMV-WE at the indicated time points $(\mathrm{n}=4)(\mathrm{C})$ Bile acid titers measured at the indicated time points in C57BL/6 wild-type (WT) and CD8 ${ }^{-/-}$mice intravenously infected with $2^{\mathrm{x}} 10^{6}$ PFU LCMV-WE $(\mathrm{n}=3-4)$. The figure was adapted from diploma thesis of Caroline Krings Heinrich-Heine-University Düsseldorf. ${ }^{*} P<0.5$; ${ }^{* *} P<0.01$; ${ }^{* * *} P<0.001$. Statistical significance was detected by Student's $t$-test (B; LDH) or analysis of variance (ANOVA; A, B; AST, ALT, and bilirubin and C). 
Fig. 2. Lymphocytic choriomeningitis virus persists in farnesoid X receptor-knockout mice. (A-B) C57BL/6 wild-type (WT) and farnesoid $\mathrm{X}$ receptorknockout $\left(\mathrm{FXR}^{-/-}\right)$mice were intravenously infected with $2^{\mathrm{x}} 10^{4}$ plaqueforming units (PFU) lymphocytic choriomeningitis virus strain WE (LCMVWE).(A) LCMV titers in various organs of $\mathrm{C} 57 \mathrm{BL} / 6$ $\mathrm{WT}$ and $\mathrm{FXR}^{-/-}$mice were measured after 5 days of infection ( $\mathrm{n}=4)$. (B) Immunofluorescence of liver sections from C57BL/6 and $\mathrm{FXR}^{-1-}$ mice 5 days after LCMV-WE infection, stained for F4/80 (Kupffer cells; red) and LCMV-NP (nucleoprotein; green). Fluorescence images were captured at $20^{\mathrm{x}}$ magnification (main images) or $60^{\mathrm{x}}$ magnification (insets) with a Keyence BZ-9000E microscope. Scale bar $=$ $100 \mu \mathrm{m}$ (main images) or $25 \mu \mathrm{m}$ (insets). One of

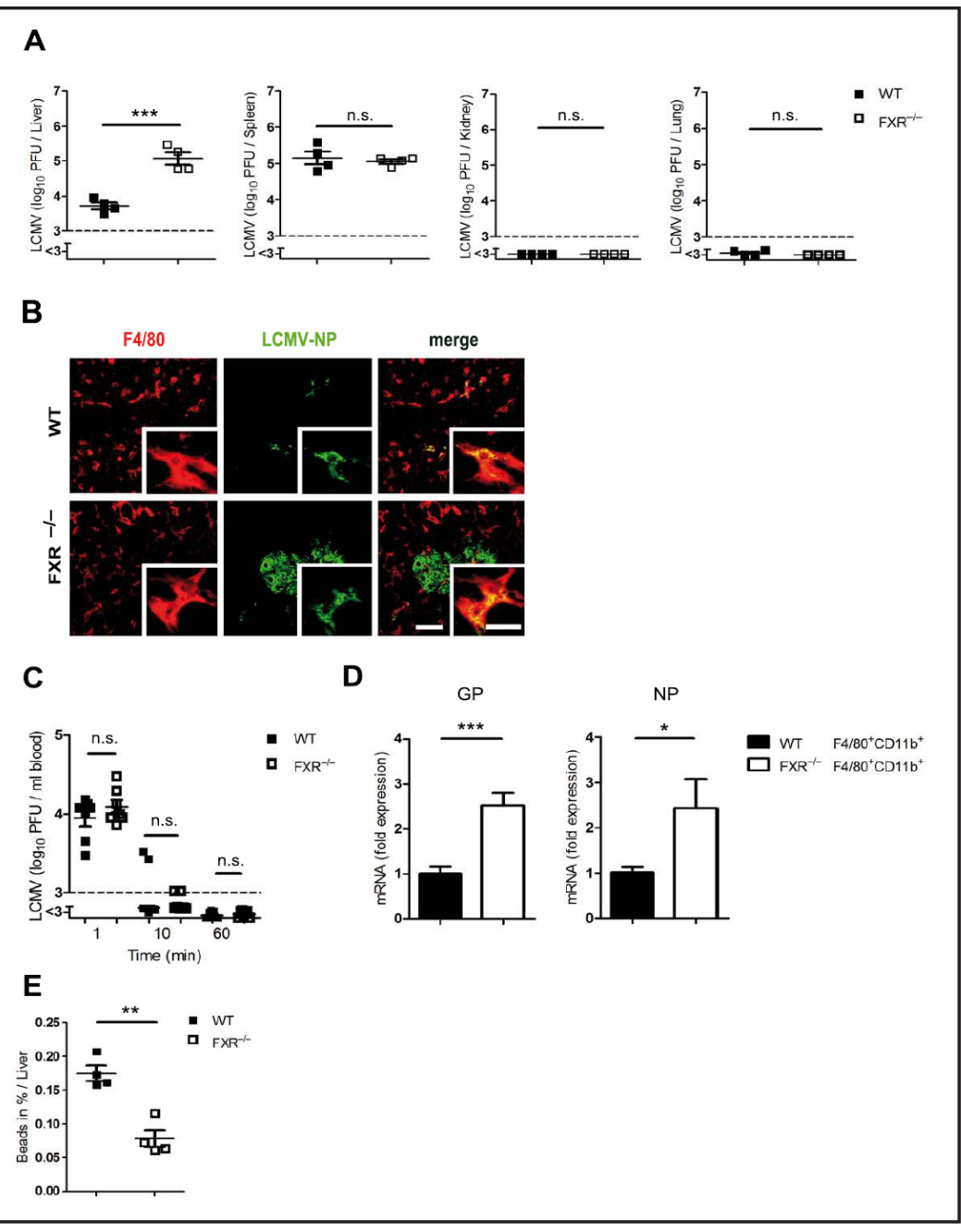

three representative images is shown $(\mathrm{n}=3)$. (C) WT and $\mathrm{FXR}^{-/-}$mice intravenously infected with $2^{\mathrm{x}} 10^{6}$ PFU LCMV. The virus uptake from blood was measured by plaque assay after 1,10 , and $60 \mathrm{~min}(\mathrm{n}=7$ pooled from 2 independent experiments). (D) WT and $\mathrm{FXR}^{-/-}$mice were intravenously infected with $2^{\mathrm{x}} 10^{4} \mathrm{PFU}$ LCMV. After 5 days of infection, $\mathrm{F} 4 / 80^{+} \mathrm{CD} 11 \mathrm{~b}^{+}$macrophages from the liver of $\mathrm{FXR}^{-/-}$and WT control mice were isolated by fluorescence-activated cell sorting (FACS). The expression of LCMV-GP and -NP was determined by quantitative real-time polymerase chain reaction (qRT-PCR; $n=5-6$ pooled from 2 independent experiments). (E) WT and FXR ${ }^{-1-}$ mice were intravenously infected with $2^{\mathrm{x}} 10^{4}$ PFU LCMV-WE. After 5 days of infection, $9 \times 10^{8}$ fluorescent latex beads were intravenously injected into these mice. The liver's efficiency in taking up beads was measured after $1 \mathrm{~h}(\mathrm{n}=4)$. n.s. not significant; ${ }^{*} P<0.5 ;{ }^{* *} P<0.01$; ${ }^{* * *} P<0.001$. Statistical significance was detected by Student's $t$-test (A, C, D, and E).

Next, we measured the infiltration of immune cells in the liver of WT and $\mathrm{FXR}^{-/-}$mice 5 days after LCMV infection (Fig. 3C). We observed a reduction in the number of Ly6C $\mathrm{C}^{+} \mathrm{Ly} 6 \mathrm{G}^{+}$

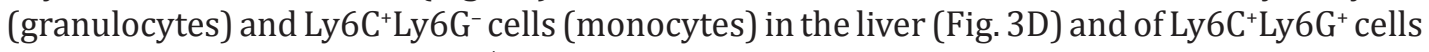
in the blood and spleen of $\mathrm{FXR}^{-/-}$mice (Fig. 3E) but there was no significant difference in the myeloid populations in the bone marrow of naive mice (Fig. 3F). This suggests that initially, $\mathrm{FXR}^{-/-}$mice do not have defect in the generation of myeloid cells. We questioned whether the inhibition of monocyte expansion was due to the absence of FXR or to high levels of BAs. To answer this question, we first treated bone marrow cells from WT or FXR ${ }^{-/-}$mice with CDCA or left the cells untreated as control. CDCA is considered to be the strongest FXR agonist at the half maximal effective concentration $\left(\mathrm{EC}_{50}\right)$ of $50 \mu \mathrm{M}[34,44]$. After this, cells were stimulated with granulocyte-macrophage colony-stimulating factor (GM-CSF). Activation 
Fig. 3. Farnesoid $\mathrm{X}$ receptor increases the infiltration of immune cells to the infected organs (A) WT and FXR $^{-/}$mice were infected with LCMV-WE. On day 5 after infection with $2^{\mathrm{x}} 10^{4}$ plaqueforming units (PFU) of LCMV, $\mathrm{F} 4 / 80{ }^{+} \mathrm{CD} 11 \mathrm{~b}^{+}$ cells in the liver were sorted by FACS. The expression of antiviral genes Oas1 and Mx1 was measured by qRT-PCR ( $\mathrm{n}=4)$. (B) WT and $\mathrm{FXR}^{-1-}$ mice were intravenously infected with $2^{\mathrm{x}} 10^{6}$ PFU LCMV-WE or left uninfected. On day 6 after infection, the expression of Ifn $\alpha 4$ and Ifn $\beta 1$ was measured in naïve and infected livers ( $\mathrm{n}$ = 4-5). (C-E) WT and $\mathrm{FXR}^{-/-}$mice were infected with $2^{\mathrm{x}} 10^{4}$ PFU LCMV-
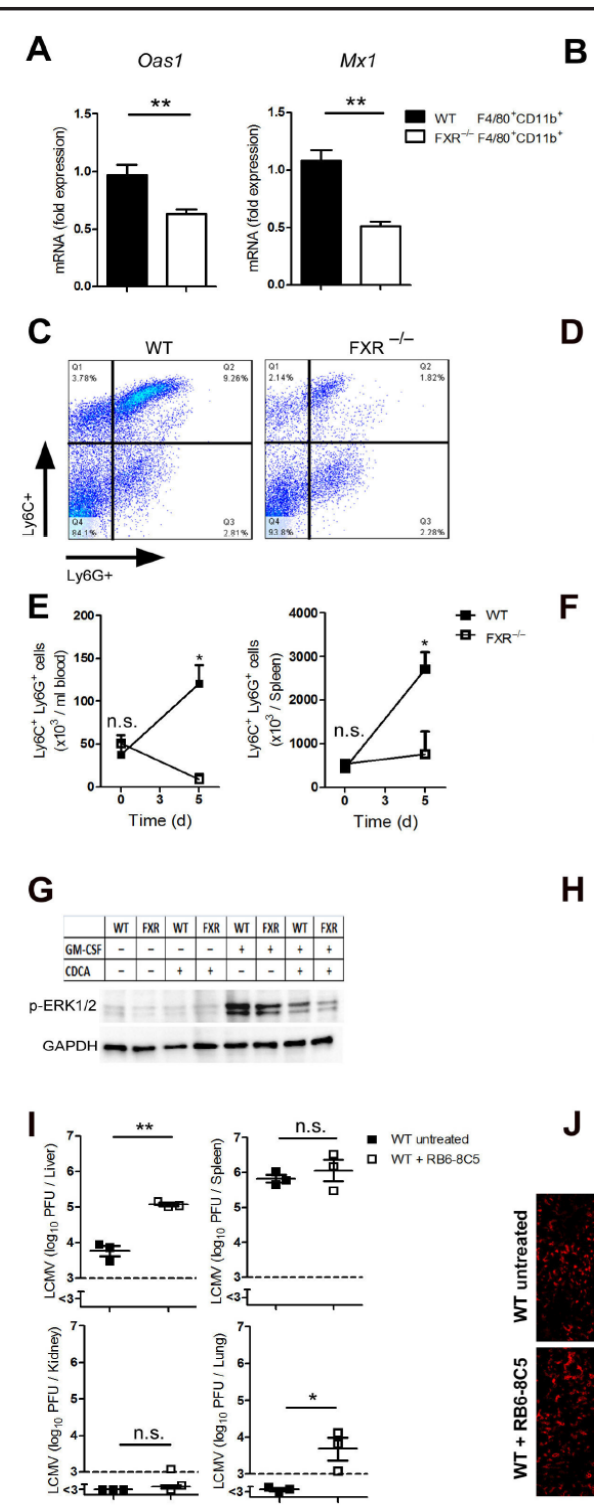

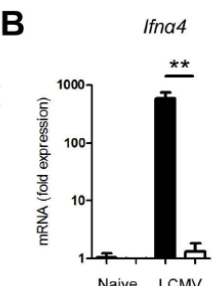

D

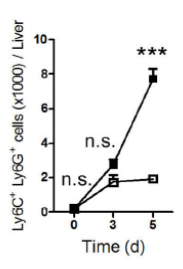

F
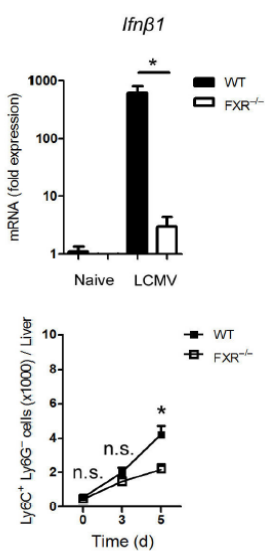

i. WT $_{\text {FXR }}^{-1-}$

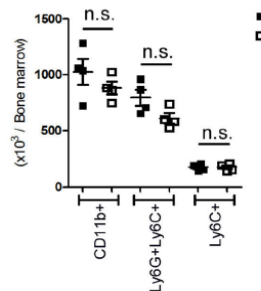

H
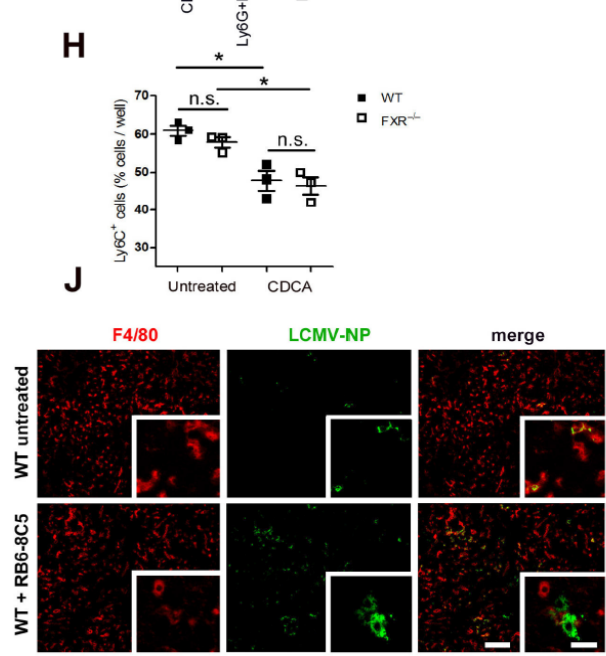

WE. On day 5 after infection, Ly6C+Ly6G+ cells were counted in the liver by FACS (C; $n=3)$. Ly6C $\mathrm{Ly}^{+} 6 \mathrm{G}^{+}$and Ly $6 \mathrm{C}^{+} \mathrm{Ly}_{6 \mathrm{G}^{-}}$cells were measured in the liver under naïve conditions and on day 3 and 5 after infection (D; $\mathrm{n}=$ $3-4)$. Ly6 $\mathrm{C}^{+} \mathrm{Ly}_{6 \mathrm{G}}{ }^{+}$cells were measured in the blood and spleen in naïve mice and on day 5 after infection (E; $\mathrm{n}$ = 3-4). (F-H) Bone marrow cells were isolated from naïve WT and $\mathrm{FXR}^{-/-}$mice. Indicated cells were analyzed by FACS (F; $\mathrm{n}=4) .2^{\mathrm{x}} 10^{6}$ bone marrow cells were treated with the endogeneous FXR ligand chenodeoxycholic acid (CDCA, 50 $\mu \mathrm{M}$ ) for 15 minutes or left untreated before incubation with GM-CSF for additional 15 minutes. Phospho-ERK1/2 (pERK1/2) and GAPDH was measured in total cell extracts by immunoblotting. One of three representative blots is shown ( $\mathrm{G} ; \mathrm{n}=3$ ). $2^{\mathrm{x}} 10^{6}$ bone marrow cells were treated with GM-CSF in the presence or absence of CDCA $(100 \mu \mathrm{M})$. After 5 days, Ly6C cells were analyzed by FACS $(H ; n=3)$. (I) WT mice were intravenously infected with $2 \times 10^{4}$ PFU LCMV-WE. On day 3 after infection, mice were treated with RB6-8C5 antibody or left untreated. LCMV titers in liver, spleen, kidney, and lung were measured on day $5(\mathrm{n}=3)$. (J) Immunofluorescence of liver sections stained for F4/80 (red) and LCMV-NP (nucleoprotein; green). Fluorescent images were captured at $20^{\mathrm{x}}$ magnification with a Keyence BZ-9000E microscope. Scale bars, $100 \mu \mathrm{m}$ (main images) or $25 \mu \mathrm{m}$ (insets). One of three representative images is shown $(\mathrm{n}=3)$. n.s., not significant; ${ }^{*} P<0.5$; ${ }^{* *} P<0.01$; ${ }^{* *} P<0.001$. Statistical significance was detected by Student's $t$-test (A, B, D, E, F, H and I). 


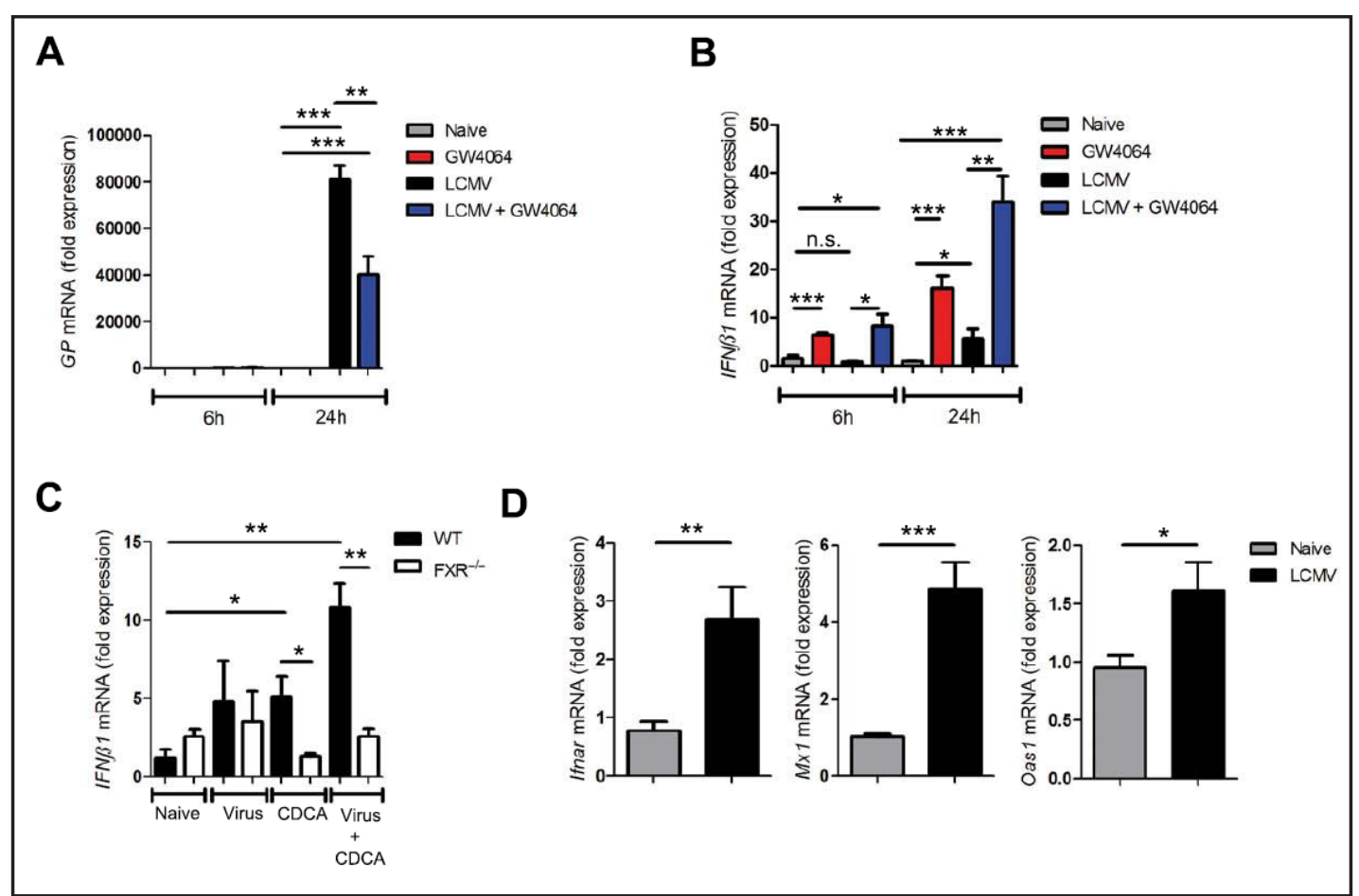

Fig. 4. Farnesoid $X$ receptor activation in hepatocytes leads to production of type I interferon. (A-B) Primary hepatocytes from wild-type (WT) mice were infected with lymphocytic choriomeningitis virus strain WE (LCMV-WE) or left uninfected. Cells were treated with the synthetic farnesoid X receptor (FXR) agonist GW4064 $(1 \mu \mathrm{M})$ or left untreated. After 6 and $24 \mathrm{~h}$, virus glycoprotein gene expression (LCMV-GP) (A) or interferon beta 1 (IFN $\beta 1$ ) gene expression (B) was measured by quantitative real-time polymerase chain reaction (qRT-PCR) ( $\mathrm{n}=5-6$ pooled from 2 independent experiments). (C) WT and $\mathrm{FXR}^{-/-}$primary hepatocytes were infected with LCMV-WE or left uninfected. Cells were treated with the FXR agonist chenodeoxycholic acid (CDCA; $50 \mu \mathrm{M}$ ) or left untreated. After $24 \mathrm{~h}$, IFN $\beta 1$ expression was measured in these cells (n = 3). (D) Primary hepatocytes from WT mice were infected with LCMV-WE or left uninfected. Type I interferon receptor (Ifnar), myxovirus (influenza) resistance $1(M x 1)$ and 2 ` $^{`}{ }^{-}$-oligoadenylate synthetase 1 (Oas1) gene expression was measured after $24 \mathrm{~h}$ by qRT-PCR ( $\mathrm{n}=6$ pooled from 2 independent experiments). n.s., not significant; ${ }^{*} P<0.5$; $^{* *} P<0.01$; ${ }^{* *} P<0.001$. Statistical significance was detected by Student's $t$-test $(\mathrm{A}, \mathrm{B}$, C, and D).

with GM-CSF was assessed by measuring phosphorylation of ERK (Fig. 3G). In bone marrow cells of WT or $\mathrm{FXR}^{-/-}$mice treated in vitro with CDCA phosphorylation of ERK was reduced (Fig. 3G) which means that CDCA can inhibit the effect of GM-CSF independently of FXR.

To analyze the effect of BAs on the proliferation of Ly $6 \mathrm{C}^{+}$cells, we treated bone marrow cells with GM-CSF in the presence or absence of CDCA. After 5 days, we noticed a reduction in the number of Ly6 $\mathrm{C}^{+}$cells after treatment with CDCA (Fig. $3 \mathrm{H}$ ). This reduction was not FXRdependent because FXR-deficient as well as WT bone marrow cells had reduced numbers of Ly6C $\mathrm{C}^{+}$cells in the presence of CDCA (Fig. $3 \mathrm{H}$ ). Again, this finding means that bile acids (BAs) can inhibit GM-CSF signaling independent of FXR.

To study the role of $\mathrm{Ly}_{6 \mathrm{C}} \mathrm{C}^{+} \mathrm{Ly} 6 \mathrm{G}^{+}$granulocytes and $\mathrm{Ly} 6 \mathrm{C}^{+} \mathrm{Ly} 6 \mathrm{G}^{-}$monocytes during $\mathrm{LCMV}$ infection, we depleted these cell populations early after viral infection by using a monoclonal anti-Gr-1 antibody (clone RB6-8C5). This antibody recognizes both antigens Ly6G and Ly6C [45]. Like FXR-deficient mice, RB6-8C5-treated WT mice, which lacked these cell populations, exhibited an increase in viral replication in the liver and, to a lesser extent, in the lung, but exhibited no change in viral replication in the spleen and kidney (Fig. 3I). Histological staining showed more viral replication in Kupffer cells and in a few single localized hepatocytes in RB6-8C5-treated mice (Fig. 3J). 


\section{Cellular Physiology Cell Physiol Biochem 2017;41:323-338

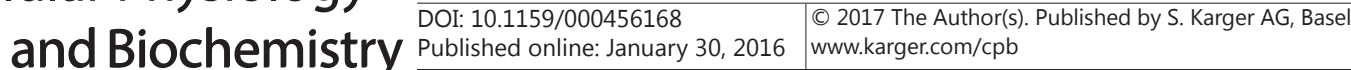

Honke et al.: FXR Prevents Immunopathology During LCMV Infection

In conclusion, we found that the absence of FXR leads to high BA levels, which influence monocyte expansion by inhibiting the GM-CSF signaling pathway and consequently affects the viral control. The ability of BAs in reducing GM-CSF signaling was FXR-independent.

FXR activation in hepatocytes leads to production of IFN-I

To study the role of FXR in hepatocytes during LCMV infection independent of the effect of BAs, we infected primary hepatocytes with LCMV in the presence or absence of the synthetic FXR agonist GW4064. Interestingly, we found that activation of FXR led to the inhibition of viral replication (Fig. 4A). The antiviral effect of FXR was due to the upregulation of IFN $\beta 1$ in hepatocytes (Fig. 4B). Even without infection, the activation of FXR with GW4064 led to significantly higher IFN $\beta 1$ expression (Fig. 4B). Similarly, after LCMV infection of WT or $\mathrm{FXR}^{-/-}$hepatocytes in the presence or absence of the FXR agonist CDCA, the expression of IFN $\beta 1$ was highest in hepatocytes in which FXR was activated with CDCA, whereas FXR-deficient hepatocytes showed no upregulation of IFN $\beta 1$ mRNA (Fig. 4C). To determine whether the hepatocytes can respond to IFN-I, we measured the expression of the type I interferon receptor (Ifnar) and antiviral genes (Oas1, Mx1) in naive and LCMV-infected hepatocytes. A significant upregulation was detected after infection with LCMV, a finding indicating that hepatocytes can respond to the antiviral cytokine (Fig. 4D). We conclude that FXR in hepatocytes can play an antiviral role during LCMV infection.

\section{Lack of FXR potentiates $C D 8^{+} T$ cell exhaustion and viral persistence}

Next we investigated whether the absence of FXR during LCMV infection can influence the adaptive immune system. LCMV-specific CD8 ${ }^{+} \mathrm{T}$ cells in the blood and spleen were counted in infected WT and $\mathrm{FXR}^{-/-}$mice. A (normal) proliferation of $\mathrm{CD}^{+} \mathrm{T}$ cells was observed on day 8; thereafter, the proliferation of $\mathrm{CD}^{+} \mathrm{T}$ cells did not increase in $\mathrm{FXR}^{-/-}$mice (Fig. 5A, B). The function of $\mathrm{CD}^{+} \mathrm{T}$ cells was also impaired in $\mathrm{FXR}^{-/-}$mice, as determined by an insufficient ability of CD8 ${ }^{+} \mathrm{T}$ cells to produce IFN- $\gamma$ after in vitro re-stimulation with the LCMV peptide GP33 (Fig. 5C). This finding points to an exhaustion of $\mathrm{CD}^{+} \mathrm{T}$ cells in $\mathrm{FXR}^{-1-}$ mice.

To determine whether high levels of BAs can influence CD8 ${ }^{+} \mathrm{T}$ cell priming, we transferred carboxyfluorescein succinimidyl ester (CFSE)-labeled LCMV-specific CD8 ${ }^{+}$T cells (P14) to WT and $\mathrm{FXR}^{-/-}$mice on day 12 after LCMV infection at a time point at which BA levels are high. $\mathrm{CD}^{+} \mathrm{T}$ cells proliferated similarly in WT and $\mathrm{FXR}^{-1-}$ mice, a finding indicating that high levels of BAs do not alter $\mathrm{CD}^{+} \mathrm{T}$ cell priming (Fig. 5D). To determine whether the absence of monocytes and granulocytes can lead to impairment of $\mathrm{CD}^{+} \mathrm{T}$ cells, we counted $\mathrm{CD} 8^{+} \mathrm{T}$ cells in WT mice after treatment with the RB6-8C5 antibody. Indeed, the absence of monocytes or granulocytes was associated with a reduction in the number of LCMV-specific CD8 ${ }^{+} \mathrm{T}$ cells in treated mice, as compared to untreated mice (Fig. 5E). The exhaustion of CD8 ${ }^{+} \mathrm{T}$ cells in $\mathrm{FXR}^{-/-}$mice was accompanied by viral persistence in liver, spleen, lung and kidney (Fig. 5F). From these results, we conclude that the absence of FXR leads to exhaustion of CD8 ${ }^{+} \mathrm{T}$ cells and to viral persistence.

Intrinsic expression of FXR has no impact on immune cells

To determine whether the defect in granulocyte and monocyte infiltration, the impaired virus-specific $\mathrm{T}$ cell number and virus control in $\mathrm{FXR}^{-/-}$mice was immune cell intrinsic, we developed bone marrow chimeras by engrafting $\mathrm{FXR}^{-1-}$ or control WT bone marrow into $\mathrm{FXR}^{-/-}$or WT mice. Mice were irradiated and reconstituted with donor bone marrow, and treated at day 15 with liposomal clodronate to exchange the resident Kupffer cells as well. 30 days after reconstitution, chimeric mice were infected with LCMV. $\mathrm{FXR}^{-/-}$mice that received bone marrow from WT donor mice exhibited lower infiltration of granulocytes into the liver (Fig. 6A), whereas grafting $\mathrm{FXR}^{-/-}$bone marrow into WT recipients restored the number of patrolling granulocytes in the liver to normal levels (Fig. 6A). Moreover, at later time points, only $\mathrm{FXR}^{-/-}$mice exhibited a lower number of LCMV-specific CD8 ${ }^{+} \mathrm{T}$ cells, whereas the intrinsic absence of FXR in immune cells did not influence the number of $\mathrm{CD}^{+} \mathrm{T}$ cells in spleen and liver (Fig. 6B). Next we wanted to ensure that the absence of FXR in immune 
Fig. 5. Lack of farnesoid $X$ receptor potentiates $\mathrm{CD}^{+} \mathrm{T}$ cell exhaustion and viral persistence. (A-C) C57BL/6 wild-type (WT) and farnesoid $\mathrm{X}$ receptor-knockout $\left(\mathrm{FXR}^{-/-}\right)$mice were infected with $\quad 2^{\mathrm{x}} 10^{6}$ plaque-forming units (PFU) lymphocytic choriomeningit is virus strain WE (LCMV-WE). Fluorescence-activated cell sorting (FACS) analysis of total $\mathrm{CD}^{+} \mathrm{T}$ cells and virusspecific GP33 ${ }^{+}$ $\mathrm{CD}^{+} \mathrm{T}$ cells measured in blood at the indicated time points (A) and spleen on day 12 (B) ( $\mathrm{n}=6-8$ pooled from 2 in-
B
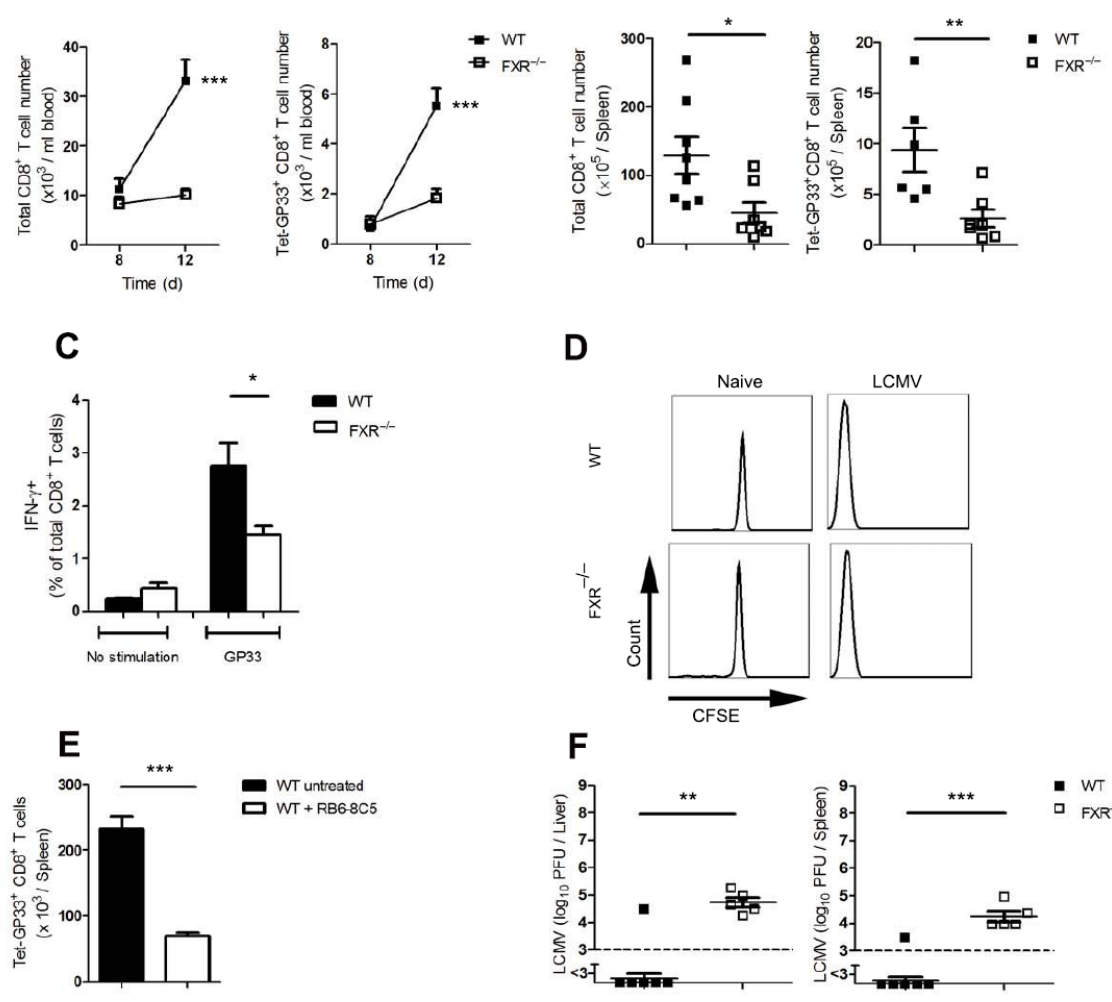

。
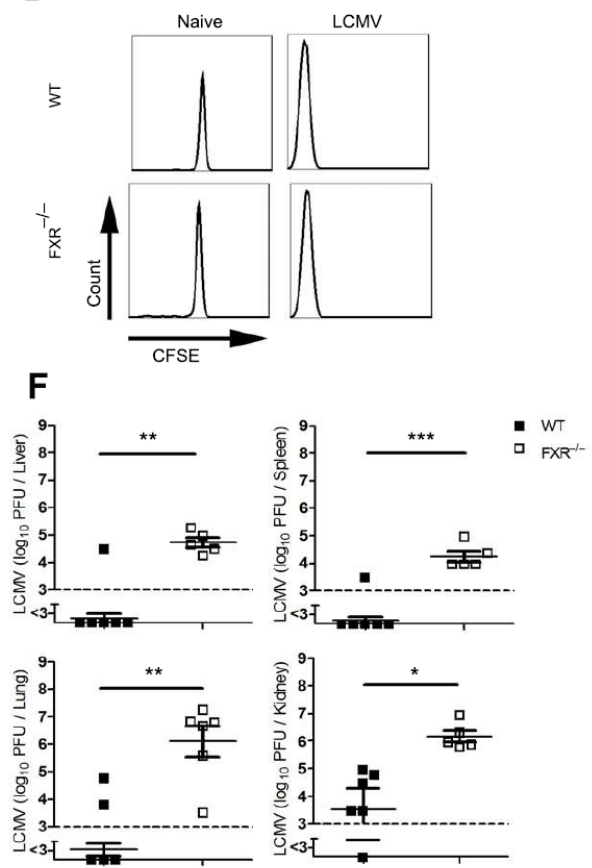

dependent experiments). (C) FACS analysis of interferon gamma (IFN- $\gamma^{+}$) CD8 ${ }^{+}$T cells measured in splenocytes on day 12 after infection without or after restimulation with GP33-peptide for 6 hours (n = 3). (D) WT and $\mathrm{FXR}^{-/-}$mice were intravenously infected with $2^{\mathrm{x}} 10^{6}$ PFU LCMV-WE. After 12 days of infection, 107 splenocytes from P14/CD45.1 mice were labeled with carboxyfluorescein succinimidyl ester (CFSE) and transferred into infected C57BL/6 WT or $\mathrm{FXR}^{-/-}$mice. Proliferation of CD45.1 ${ }^{+} \mathrm{CD}^{+} \mathrm{T}$ cells was assessed by CFSE dilution in the spleen 2 days after transfer. Blots show cells gated on CD $45.1^{+} \mathrm{CD}^{+} \mathrm{T}$ cells. One representative set of data is shown $(\mathrm{n}=3)$. (E) C57BL/6 WT mice were intravenously infected with $2 \times 10^{4} \mathrm{PFU}$ LCMV-WE. On days 3, 5, and 11 after infection, mice were treated with RB6-8C5 antibody or left untreated. FACS analysis of virus-specific GP33 ${ }^{+} \mathrm{CD}^{+} \mathrm{T}$ cells measured on day 12 after infection in the spleen of treated or untreated WT mice $(\mathrm{n}=5)$. (F) WT and $\mathrm{FXR}^{-/-}$mice were infected with $2^{\mathrm{x}} 10^{6}$ PFU LCMV-WE. Viral titers were analyzed in the indicated organs by plaque assay on day 12 after infection ( $n=5-6$ pooled from 2 independent experiments). ${ }^{*} P<0.5$; ${ }^{* *} P<0.01$; ${ }^{* * *} P<0.001$. Statistical significance was detected by Student's $t$-test (B, C, E, and F) or analysis of variance (ANOVA) (A).

cells exerts no influence on viral control. Measurements of viral titer in various organs showed that the viral titer was independent of the presence or absence of FXR in immune cells (Fig. 6C). These results exclude the role of FXR in immune cells, a finding indicating that FXR expression in non-immune cells prevents severe liver immunopathology during LCMV infection. 
Fig. 6. Intrinsic expression of farnesoid X receptor has no impact on immune cells. Wild-type (WT) and farnesoid X receptorknockout $\left(\mathrm{FXR}^{-/-}\right)$mice were lethally irradiated and one day later were reconstituted with $10^{7}$ bone marrow cells from either $\mathrm{FXR}^{-/-}$or WT control mice. On day 15, all recipient mice were intravenously treated with clodronate liposomes. Thirty days later, mice were infected with $2^{\mathrm{x}} 10^{4}$ plaqueforming units (PFU; A and C) or $2^{\mathrm{x}} 10^{6} \mathrm{PFU}$ (B) lymphocytic choriomeningitis virus strain WE (LCMV-WE). (A) The number of $\mathrm{Ly}_{6 \mathrm{G}^{+}}$and Ly $6 \mathrm{C}^{+}$cells was measured in the liver on day 5 after LCMV infection ( $n=4-5$ pooled from 2 independent experiments). (B) Virus-specific GP33+ ${ }^{+}$C $8{ }^{+} \mathrm{T}$ cells in the spleen and liver were counted by flow cytometry on day 12 after LCMV-WE infection (spleen, $n=6-7$; liver, $n=4-5$ pooled from two independent experiments). (C) Viral titer in various organs measured on day 5 after infection $(\mathrm{n}=3)$. n.s., not significant, $* P$ $<0.5$; ${ }^{* *} P<0.01$. Statistical significance was detected by Student's $t$-test (A, B, and C).

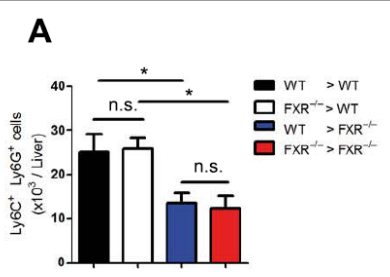

B
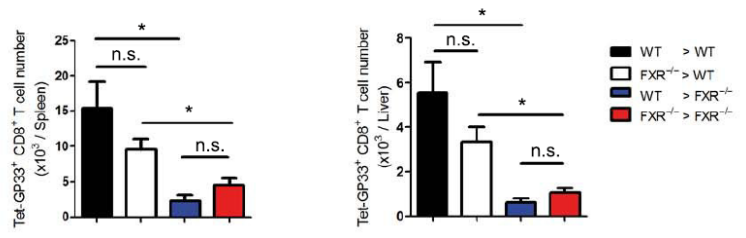

C
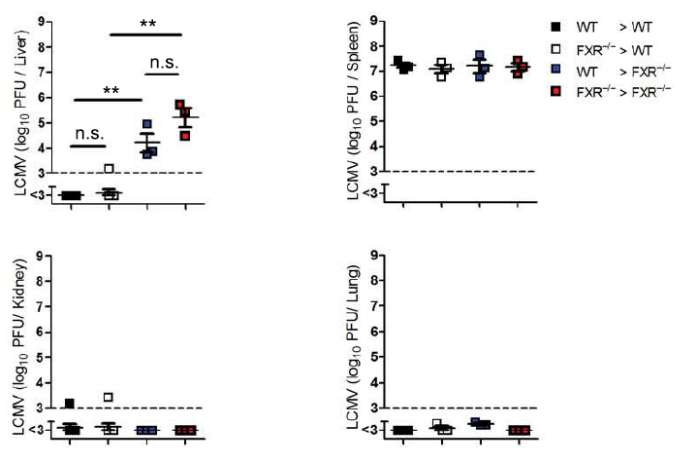

Fig. 7. Role of farnesoid X receptor during lymphocytic choriomeningitis virus infection. Illustrated figure of the role of farnesoid X receptor (FXR) during lymphocytic choriomeningitis virus strain WE (LCMV-WE) infection. WT, wild-type; $\mathrm{FXR}^{-/-}$, FXR knockout; IFN $\beta$, interferon beta; GM-CSF, granulocyte-macrophage colony-stimulating factor.

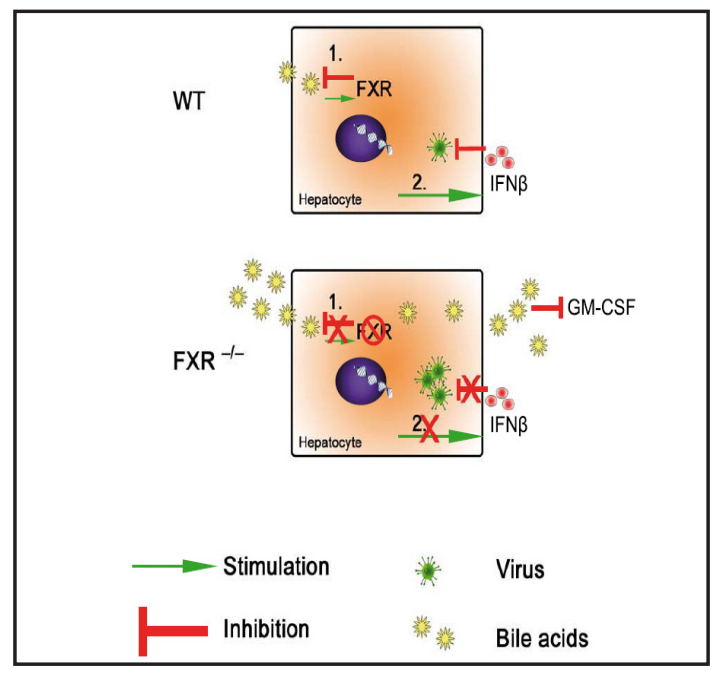

\section{Discussion}

The results of the current study showed that FXR expression in hepatocytes is very important for sensing free BAs during LCMV infection which are released from hepatocytes in a $\mathrm{CD}^{+} \mathrm{T}$ cell-dependent manner. Activation of the nuclear receptor FXR led to upregulation of IFN-I expression. Additionally, FXR inhibits the hyperproduction of BAs, thereby avoiding their toxic effect on monocyte proliferation and infiltration into the liver. This infiltration 
was essential in helping Kupffer cells to control viral infection. The absence of FXR reduces IFN-I production and the proliferation and patrolling of immune cells in the liver and leads to higher viral replication (Fig. 7) and, consequently, to severe immunopathology and CD8 ${ }^{+}$ $\mathrm{T}$ cell exhaustion.

The functionality of Kupffer cells is crucial during viral infection. Their role is not limited to capturing viral particles; they also inhibit viral replication in an IFN-I-dependent manner $[42,43]$. Additional study showed that prevention of liver disease during viral infection is mediated by macrophages through getting IFN-I support from plasmacytoid dendritic cells (pDCs) [46]. In this study, we found that in the liver IFN-I production is FXR-dependent. Moreover, during infection, FXR guarantees granulocyte and monocyte infiltration into the liver, where these cells assist Kupffer cells in viral control. During bacterial infection, the efficiency of Kupffer cells in the elimination of bacteria depends rather more on the interaction between these cells and granulocytes than on their own ability to phagocytize and digest bacteria $[47,48]$. In this study, we found that monocytes and granulocytes that infiltrate the liver during LCMV infection can assist Kupffer cells in controlling virus. However, it remains to be determined whether the direct interaction of monocytes and granulocytes with Kupffer cells is sufficient to overcome viral infection or whether monocytes and granulocytes have additional mechanism by which they participate in antiviral control.

The fact that hepatocytes can upregulate the expression of IFNAR and antiviral genes during infection and can inhibit viral replication in an IFN-I-dependent manner illustrates their contribution to viral control. Similar results were also observed by using immortalized human hepatocytes showing that HCV can induce IFN $\beta$ and the antiviral protein 2 ',5'-oligoadenylate synthetase 1 (Oas1) mRNA expression [49]. This finding raises the question: which role do BAs play during HCV infection, and consequently, is FXR involved in this process. However, other study showed that cholestasis and BAs induced during chronic viral infection seem to play a role in resistance to IFN because they can inhibit the induction of antiviral proteins $[3,50,51]$. Our results show that BAs can play a yin and yang role in viral control. On one hand, it leads to IFN-I production through FXR activation, on the other hand, it inhibits monocytes and granulocytes expansion.

As we mentioned above, FXR is not only expressed in hepatocytes but also in other organs like kidney and intestine [28-30]. Although our in vitro results showed that FXR and BAs have a direct effect in the upregulation of IFN $\beta 1$ expression and inhibiting GM-CSF signaling, it should be taken in consideration that FXR regulates also the expression of the ileal bile acid transporters, such as ASBT, OST $\alpha$-OST $\beta$ and the cytosolic ileal bile acid binding protein IBABP (FABP6) $[52,53]$, which may modify gastrointestinal tract physiology and food absorption and consequently can influence the immune response.

Although some studies have found that FXR is also expressed in RAW264.7 macrophages, blood-derived macrophages, and Kupffer cells $[12,54]$ our study showed that the absence of FXR in immune cells does not influence LCMV control, whereas the absence of FXR in nonimmune cells is crucial in reducing viral replication and maintaining the efficiency of the adaptive immune system.

In conclusion, we found that FXR expression by hepatocytes plays an important role in overcoming viral infection, inhibition of $\mathrm{T}$ cell exhaustion and preventing immunopathology.

\section{Acknowledgments}

We thank Konstanze Schättel for technical support. The National Institutes of Health (NIH, Bethesda, MD, USA) Tetramer Core Facility provided the tetramers. FACS sorting was performed by Prof. M. Gunzer, West German Tumor Center (WTZ), at the Imaging Center Essen (IMCES) of University Hospital Essen. 


\section{Cellular Physiology Cell Physiol Biochem 2017;41:323-338

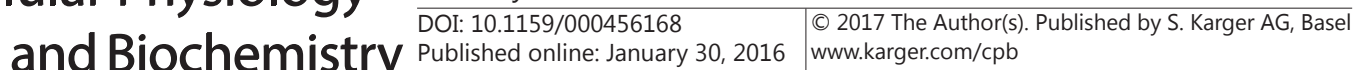

Honke et al.: FXR Prevents Immunopathology During LCMV Infection

\section{Disclosure Statement}

The authors declare no sponsorship or funding arrangements to their research and have no competing financial interests.

\section{References}

$>1$ Allen K, Jaeschke H, Copple BL: Bile acids induce inflammatory genes in hepatocytes: A novel mechanism of inflammation during obstructive cholestasis. Am J Pathol 2010;178:175-186.

-2 Scholtes C, Diaz O, Icard V, Kaul A, Bartenschlager R, Lotteau V, Andre P: Enhancement of genotype 1 hepatitis c virus replication by bile acids through fxr. J Hepatol 2008;48:192-199.

3 Kim HY, Cho HK, Choi YH, Lee KS, Cheong J: Bile acids increase hepatitis b virus gene expression and inhibit interferon-alpha activity. FEBS J 2010;277:2791-2802.

4 Ramiere C, Scholtes C, Diaz O, Icard V, Perrin-Cocon L, Trabaud MA, Lotteau V, Andre P: Transactivation of the hepatitis b virus core promoter by the nuclear receptor fxralpha. J Virol 2008;82:10832-10840.

5 Kawamata Y, Fujii R, Hosoya M, Harada M, Yoshida H, Miwa M, Fukusumi S, Habata Y, Itoh T, Shintani Y, Hinuma S, Fujisawa Y, Fujino M: A g protein-coupled receptor responsive to bile acids. J Biol Chem 2003;278:9435-9440.

-6 Maruyama T, Miyamoto Y, Nakamura T, Tamai Y, Okada H, Sugiyama E, Itadani H, Tanaka K: Identification of membrane-type receptor for bile acids (m-bar). Biochem Biophys Res Commun 2002;298:714-719.

-7 Maruyama T, Tanaka K, Suzuki J, Miyoshi H, Harada N, Nakamura T, Miyamoto Y, Kanatani A, Tamai Y: Targeted disruption of g protein-coupled bile acid receptor 1 (gpbar1/m-bar) in mice. J Endocrinol 2006;191:197-205.

8 Keitel V, Donner M, Winandy S, Kubitz R, Haussinger D: Expression and function of the bile acid receptor tgr5 in kupffer cells. Biochem Biophys Res Commun 2008;372:78-84.

-9 Keitel V, Reinehr R, Gatsios P, Rupprecht C, Gorg B, Selbach 0, Haussinger D, Kubitz R: The g-protein coupled bile salt receptor tgr5 is expressed in liver sinusoidal endothelial cells. Hepatology 2007;45:695704.

10 Zhang Z, Burch PE, Cooney AJ, Lanz RB, Pereira FA, Wu J, Gibbs RA, Weinstock G, Wheeler DA: Genomic analysis of the nuclear receptor family: New insights into structure, regulation, and evolution from the rat genome. Genome Res 2004;14:580-590.

11 Cipriani S, Mencarelli A, Chini MG, Distrutti E, Renga B, Bifulco G, Baldelli F, Donini A, Fiorucci S: The bile acid receptor gpbar-1 (tgr5) modulates integrity of intestinal barrier and immune response to experimental colitis. PLoS One 2011;6:e25637.

12 Renga B, Mencarelli A, Cipriani S, D'Amore C, Carino A, Bruno A, Francisci D, Zampella A, Distrutti E, Fiorucci S: The bile acid sensor fxr is required for immune-regulatory activities of tlr-9 in intestinal inflammation. PLoS One 2013;8:e54472.

$\checkmark 13$ Vavassori P, Mencarelli A, Renga B, Distrutti E, Fiorucci S: The bile acid receptor fxr is a modulator of intestinal innate immunity. J Immunol 2009;183:6251-6261.

14 Mencarelli A, Renga B, Migliorati M, Cipriani S, Distrutti E, Santucci L, Fiorucci S: The bile acid sensor farnesoid $\mathrm{x}$ receptor is a modulator of liver immunity in a rodent model of acute hepatitis. J Immunol 2009;183:6657-6666.

15 Meng Z, Wang Y, Wang L, Jin W, Liu N, Pan H, Liu L, Wagman L, Forman BM, Huang W: Fxr regulates liver repair after ccl4-induced toxic injury. Mol Endocrinol 2010;24:886-897.

16 Inagaki T, Moschetta A, Lee YK, Peng L, Zhao G, Downes M, Yu RT, Shelton JM, Richardson JA, Repa JJ, Mangelsdorf DJ, Kliewer SA: Regulation of antibacterial defense in the small intestine by the nuclear bile acid receptor. Proc Natl Acad Sci U S A 2006;103:3920-3925.

17 Huang XF, Zhao WY, Huang WD: Fxr and liver carcinogenesis. Acta Pharmacol Sin 2015;36:37-43.

18 Zhang Y, Ge X, Heemstra LA, Chen WD, Xu J, Smith JL, Ma H, Kasim N, Edwards PA, Novak CM: Loss of fxr protects against diet-induced obesity and accelerates liver carcinogenesis in ob/ob mice. Mol Endocrinol 2012;26:272-280. 


\section{Cellular Physiology Cell Physiol Biochem 2017;41:323-338 \begin{tabular}{l|l|l}
\hline DOI: 10.1159/000456168 30,2016 & $\begin{array}{l}\text { C) } 2017 \text { The Author(s). Published by S. Karger AG, Basel } \\
\text { www.karger.com/cpb }\end{array}$ \\
\hline Publiochemistry
\end{tabular}}

Honke et al.: FXR Prevents Immunopathology During LCMV Infection

19 Wang YD, Chen WD, Wang M, Yu D, Forman BM, Huang W: Farnesoid x receptor antagonizes nuclear factor kappab in hepatic inflammatory response. Hepatology 2008;48:1632-1643.

-20 Nijmeijer RM, Gadaleta RM, van Mil SW, van Bodegraven AA, Crusius JB, Dijkstra G, Hommes DW, de Jong DJ, Stokkers PC, Verspaget HW, Weersma RK, van der Woude CJ, Stapelbroek JM, Schipper ME, Wijmenga C, van Erpecum KJ, Oldenburg B: Farnesoid x receptor (fxr) activation and fxr genetic variation in inflammatory bowel disease. PLoS One 2011;6:e23745.

-21 Li J, Kuruba R, Wilson A, Gao X, Zhang Y, Li S: Inhibition of endothelin-1-mediated contraction of hepatic stellate cells by fxr ligand. PLoS One 2010;5:e13955.

-22 Fiorucci S, Antonelli E, Rizzo G, Renga B, Mencarelli A, Riccardi L, Orlandi S, Pellicciari R, Morelli A: The nuclear receptor shp mediates inhibition of hepatic stellate cells by fxr and protects against liver fibrosis. Gastroenterology 2004;127:1497-1512.

-23 Liu Y, Binz J, Numerick MJ, Dennis S, Luo G, Desai B, MacKenzie KI, Mansfield TA, Kliewer SA, Goodwin $\mathrm{B}$, Jones SA: Hepatoprotection by the farnesoid x receptor agonist gw4064 in rat models of intra- and extrahepatic cholestasis. J Clin Invest 2003;112:1678-1687.

24 Renga B, Mencarelli A, Vavassori P, Brancaleone V, Fiorucci S: The bile acid sensor fxr regulates insulin transcription and secretion. Biochim Biophys Acta 2010;1802:363-372.

25 Claudel T, Staels B, Kuipers F: The farnesoid x receptor: A molecular link between bile acid and lipid and glucose metabolism. Arterioscler Thromb Vasc Biol 2005;25:2020-2030.

-26 Goodwin B, Jones SA, Price RR, Watson MA, McKee DD, Moore LB, Galardi C, Wilson JG, Lewis MC, Roth ME, Maloney PR, Willson TM, Kliewer SA: A regulatory cascade of the nuclear receptors fxr, shp-1, and lrh-1 represses bile acid biosynthesis. Mol Cell 2000;6:517-526.

27 Inagaki T, Choi M, Moschetta A, Peng L, Cummins CL, McDonald JG, Luo G, Jones SA, Goodwin B, Richardson JA, Gerard RD, Repa JJ, Mangelsdorf DJ, Kliewer SA: Fibroblast growth factor 15 functions as an enterohepatic signal to regulate bile acid homeostasis. Cell Metab 2005;2:217-225.

28 Gadaleta RM, van Mil SW, Oldenburg B, Siersema PD, Klomp LW, van Erpecum KJ: Bile acids and their nuclear receptor fxr: Relevance for hepatobiliary and gastrointestinal disease. Biochim Biophys Acta 2010;1801:683-692.

-29 Wang YD, Chen WD, Moore DD, Huang W: Fxr: A metabolic regulator and cell protector. Cell Res 2008;18:1087-1095.

-30 Forman BM, Goode E, Chen J, Oro AE, Bradley DJ, Perlmann T, Noonan DJ, Burka LT, McMorris T, Lamph WW, Evans RM, Weinberger C: Identification of a nuclear receptor that is activated by farnesol metabolites. Cell 1995;81:687-693.

-31 Li Z, Kruijt JK, van der Sluis RJ, Van Berkel TJ, Hoekstra M: Nuclear receptor atlas of female mouse liver parenchymal, endothelial, and kupffer cells. Physiol Genomics 2013;45:268-275.

-32 Higashiyama H, Kinoshita M, Asano S: Immunolocalization of farnesoid x receptor (fxr) in mouse tissues using tissue microarray. Acta Histochem 2008;110:86-93.

-33 Makishima M, Okamoto AY, Repa JJ, Tu H, Learned RM, Luk A, Hull MV, Lustig KD, Mangelsdorf DJ, Shan B: Identification of a nuclear receptor for bile acids. Science 1999;284:1362-1365.

-34 Wang H, Chen J, Hollister K, Sowers LC, Forman BM: Endogenous bile acids are ligands for the nuclear receptor fxr/bar. Mol Cell 1999;3:543-553.

-35 Li G, G LG: Farnesoid x receptor, the bile acid sensing nuclear receptor, in liver regeneration. Acta Pharm Sin B 2015;5:93-98.

-36 Capello A, Moons LM, Van de Winkel A, Siersema PD, van Dekken H, Kuipers EJ, Kusters JG: Bile acidstimulated expression of the farnesoid $\mathrm{x}$ receptor enhances the immune response in barrett esophagus. Am J Gastroenterol 2008;103:1510-1516.

-37 Pircher H, Burki K, Lang R, Hengartner H, Zinkernagel RM: Tolerance induction in double specific t-cell receptor transgenic mice varies with antigen. Nature 1989;342:559-561.

-38 Battegay M, Cooper S, Althage A, Banziger J, Hengartner H, Zinkernagel RM: Quantification of lymphocytic choriomeningitis virus with an immunological focus assay in 24- or 96-well plates. J Virol Methods 1991;33:191-198.

-39 Van Rooijen N, Sanders A: Liposome mediated depletion of macrophages: Mechanism of action, preparation of liposomes and applications. J Immunol Methods 1994;174:83-93. 


\section{Cellular Physiology Cell Physiol Biochem 2017;41:323-338

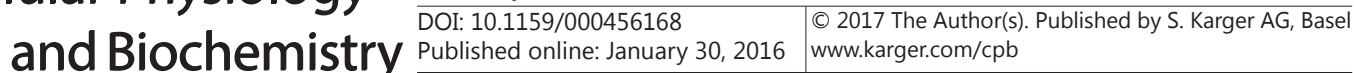

Honke et al.: FXR Prevents Immunopathology During LCMV Infection

40 Gassa A, Jian F, Kalkavan H, Duhan V, Honke N, Shaabani N, Friedrich SK, Dolff S, Wahlers T, Kribben A, Hardt C, Lang PA, Witzke O, Lang KS: Il-10 induces t cell exhaustion during transplantation of virus infected hearts. Cell Physiol Biochem 2016;38:1171-1181.

-41 Gassa A, Kalkavan H, Jian F, Duhan V, Khairnar V, Shaabani N, Honke N, Carpinteiro A, Botezatu L, Crivello P, Dolff S, Ferencik S, Haussinger D, Khandanpour C, Fleischhauer K, Witzke O, Wahlers T, Hardt C, Lang PA, Lang KS: High frequencies of anti-host reactive cd8+ t cells ignore non-hematopoietic antigen after bone marrow transplantation in a murine model. Cell Physiol Biochem 2016;38:1343-1353.

42 Lang PA, Recher M, Honke N, Scheu S, Borkens S, Gailus N, Krings C, Meryk A, Kulawik A, CervantesBarragan L, Van Rooijen N, Kalinke U, Ludewig B, Hengartner H, Harris N, Haussinger D, Ohashi PS, Zinkernagel RM, Lang KS: Tissue macrophages suppress viral replication and prevent severe immunopathology in an interferon-i-dependent manner in mice. Hepatology 2010;52:25-32.

43 Honke N, Shaabani N, Cadeddu G, Sorg UR, Zhang DE, Trilling M, Klingel K, Sauter M, Kandolf R, Gailus N, van Rooijen N, Burkart C, Baldus SE, Grusdat M, Lohning M, Hengel H, Pfeffer K, Tanaka M, Haussinger D, Recher M, Lang PA, Lang KS: Enforced viral replication activates adaptive immunity and is essential for the control of a cytopathic virus. Nat Immunol 2012;13:51-57.

44 Fiorucci S, Rizzo G, Donini A, Distrutti E, Santucci L: Targeting farnesoid x receptor for liver and metabolic disorders. Trends Mol Med 2007;13:298-309.

45 Kowanetz M, Wu X, Lee J, Tan M, Hagenbeek T, Qu X, Yu L, Ross J, Korsisaari N, Cao T, Bou-Reslan H, Kallop D, Weimer R, Ludlam MJ, Kaminker JS, Modrusan Z, van Bruggen N, Peale FV, Carano R, Meng YG, Ferrara N: Granulocyte-colony stimulating factor promotes lung metastasis through mobilization of ly6g+ly6c+ granulocytes. Proc Natl Acad Sci U S A 2010;107:21248-21255.

-46 Cervantes-Barragan L, Kalinke U, Zust R, Konig M, Reizis B, Lopez-Macias C, Thiel V, Ludewig B: Type i ifnmediated protection of macrophages and dendritic cells secures control of murine coronavirus infection. J Immunol 2009;182:1099-1106.

47 Merches K, Khairnar V, Knuschke T, Shaabani N, Honke N, Duhan V, Recher M, Navarini AA, Hardt C, Haussinger D, Tummler B, Gulbins E, Futerman AH, Hoffmann D, Lang F, Lang PA, Westendorf AM, Lang KS: Virus-induced type i interferon deteriorates control of systemic pseudomonas aeruginosa infection. Cell Physiol Biochem 2015;36:2379-2392.

48 Gregory SH, Wing EJ: Neutrophil-kupffer cell interaction: A critical component of host defenses to systemic bacterial infections. J Leukoc Biol 2002;72:239-248.

-49 Kanda T, Steele R, Ray R, Ray RB: Hepatitis c virus infection induces the beta interferon signaling pathway in immortalized human hepatocytes. J Virol 2007;81:12375-12381.

50 Serfaty L, Giral P, Loria A, Andreani T, Legendre C, Poupon R: Factors predictive of the response to interferon in patients with chronic hepatitis c. J Hepatol 1994;21:12-17.

-51 Podevin P, Rosmorduc 0, Conti F, Calmus Y, Meier PJ, Poupon R: Bile acids modulate the interferon signalling pathway. Hepatology 1999;29:1840-1847.

52 Dawson PA, Lan T, Rao A: Bile acid transporters. J Lipid Res 2009;50:2340-2357.

-53 Nakahara M, Furuya N, Takagaki K, Sugaya T, Hirota K, Fukamizu A, Kanda T, Fujii H, Sato R: Ileal bile acidbinding protein, functionally associated with the farnesoid $\mathrm{x}$ receptor or the ileal bile acid transporter, regulates bile acid activity in the small intestine. J Biol Chem 2005;280:42283-42289.

-54 Yao J, Zhou CS, Ma X, Fu BQ, Tao LS, Chen M, Xu YP: Fxr agonist gw4064 alleviates endotoxin-induced hepatic inflammation by repressing macrophage activation. World J Gastroenterol 2014;20:14430-14441. 